\title{
Aktualne i nowe strategie leczenia aktywnej orbitopatii tarczycowej
}

\author{
Current and novel strategies for the treatment for active thyroid orbitopathy
}

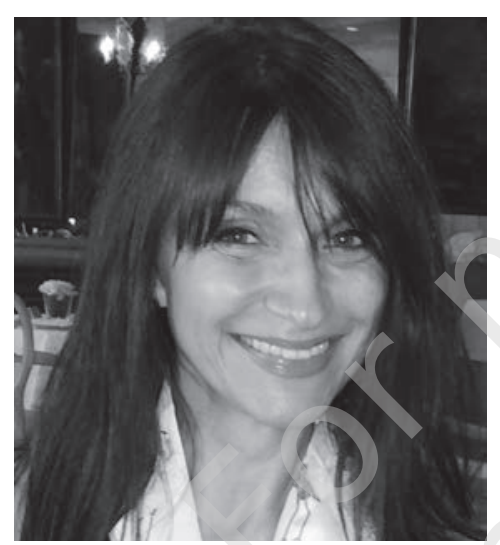

N A J W A Ż N IE J S Z E

Immunosupresja za pomocą dożylnych glikokortykosteroidów pozostaje złotym standardem leczenia oftalmopatii tarczycowej, jednak nowe strategie leczenia podążają w kierunku immunoterapii i medycyny spersonalizowanej.

\section{H I G H L I G H T S} Immunosuppression with intravenous glicocorticosteroids remains the gold standard for treating thyroid ophthalmopathy, while the new treatment strategies are moving towards immunotherapy and personalized medicine.

\section{Joanna Wierzbowska}

Klinika Okulistyki CSK MON, Wojskowy Instytut Medyczny w Warszawie Kierownik Kliniki: prof. dr hab. n. med. Marek Rękas

\section{STRESZCZENIE}

Orbitopatia tarczycowa, zwana także oftalmopatią Gravesa, jest następstwem reakcji autoimmunologicznej w oczodole wywołanej przez wspólny dla tarczycy i oczodołu antygen lub antygeny. W niniejszym artykule na podstawie koncepcji patogenezy orbitopatii tarczycowej omówiono aktualną strategię oraz nowe kierunki leczenia zarówno hipertyreozy, jak i aktywnej fazy oftalmopatii. Tradycyjna strategia leczenia orbitopatii obejmuje leczenie immunosupresyjne za pomocą glikokortykosteroidów, radioterapię oczodołów i dekompresję chirurgiczną. Nowe kierunki terapii związane są z zastosowaniem leków specyficznie modulujących określone białka komórkowe zaangażowane w szlaki reakcji autoimmunologicznej w oczodole. Należą do nich przeciwciała monoklonalne, inhibitory cytokin oraz selektywne związki immunosupresyjne.

Słowa kluczowe: oftalmopatia Gravesa, nadczynność tarczycy, autoimmunogenność, immunosupresja, glikokortykosteroidy, radioterapia, przeciwciała monoklonalne

\section{ABSTRACT}

Graves' ophthalmopathy is a consequence of an autoimmune orbital reaction that is caused by an antigen or antigens that are common to the thyroid and orbit. This review discusses the pathogenesis of thyroid orbitopathy, current treatment strategies, and new treatment options for both hyperthyroidism and the active phase of ophthalmopathy. The traditional strategy for treating Graves' ophtalmopathy involves immunosuppressive therapy with steroids, orbital radiation therapy, and surgical decompression. New treatment options include the use of drugs that modulate specific cellular proteins that are involved in orbital autoimmune pathways. These include monoclonal antibodies, cytokine inhibitors, and selective immunosuppressants.

Key words: Graves' ophthalmopathy, hyperthyroidism, autoimmunity, immunosuppression, glicocorticosteroids, radiotherapy, monoclonal antibodies 


\section{WSTĘP}

Orbitopatia tarczycowa (OT), zwana także oftalmopatią związaną z chorobami tarczycy (TAO, thyroid-associated ophthalmopathy), oftalmopatią Gravesa lub wytrzeszczem endokrynnym, jest zespołem zmian ocznych towarzyszącym autoimmunologicznym chorobom tarczycy. Orbitopatia tarczycowa w $90 \%$ przypadków towarzyszy nadczynności tarczycy w przebiegu choroby Gravesa-Basedowa i może się łączyć z innymi, pozatarczycowymi manifestacjami, takimi jak dermopatia (obrzęk przedgoleniowy) czy akropatia. W pozostałych $10 \%$ przypadków ma związek z niedoczynnością tarczycy (najczęściej typu Hashimoto) lub eutyreozą. U 85\% chorych zmiany oczne występują do 18 miesięcy przed lub po stwierdzeniu tyreotoksykozy. Klinicznie zmiany oczne stwierdza się u ok. 25-50\% chorych rasy kaukaskiej z chorobą Gravesa-Basedowa [1].

U większości z nich (90\%) zmiany te są łagodne (oftalmopatia nienaciekowa), ograniczają się do niewielkiego obrzęku tkanek miękkich i poszerzenia szpary powiekowej wskutek retrakcji powieki górnej oraz wzmożonego łzawienia i ustępują wraz z normalizacją funkcji tarczycy. U ok. 5-10\% chorych zmiany w narządzie wzroku mają postępujący przebieg i nieleczone mogą prowadzić do poważnych powikłań okulistycznych (oftalmopatia naciekowo-obrzękowa), a nawet do inwalidztwa wzrokowego i głębokiego obniżenia jakości życia [2]. OT częściej występuje u kobiet. Przewaga ta wynosi nawet 9: 1 dla zmian łagodnych i zmniejsza się wraz z nasileniem zmian do $3: 1$ dla umiarkowanej oftalmopatii i 1,4 : 1 dla ciężkich przypadków tej choroby. Największa zapadalność dotyczy dwóch grup wiekowych: 40-44 oraz 60-64 lata.

\section{PATOGENEZA}

Wystąpienie choroby Gravesa-Basedowa uwarunkowane jest działaniem trzech czynników ryzyka: genetycznego, środowiskowego i endogennego. Działanie czynnika genetycznego polega na defekcie jednego lub kilku genów układu MHC/HLA, CTLA4, TCR $\beta$ chain i łańcucha ciężkiego immunoglobulin, prowadzącym do dysregulacji układu nadzoru immunologicznego. Badania wskazują, że pierwotnymi aktywatorami powstania choroby Gravesa-Basedowa i OT są czynniki środowiskowe - palenie tytoniu, infekcje bakteryjne (Yersinia spp.), wirusowe (retrowirusy), stres, nadmierna podaż jodu w diecie. Stwierdzono, że na skutek palenia dochodzi m.in. do zmiany struktury receptora TSH (i zwiększenia jego immunogenności) oraz do zwiększonej ekspresji HLA-DR na fibroblastach oczodołów (i wzrostu produkcji glikozaminoglikanów) [3]. Głównym czynnikiem endogennym sprzyjającym wystąpieniu OT jest współistnienie innych chorób autoimmunologicznych. Na skutek zadziałania wyżej wymienionych czynników dochodzi do nieprawidłowej czynności limfocytów regula- torowych (Treg, regulatory T-cells), co wpływa na zwiększenie aktywności limfocytów B. Pobudzone limfocyty B wytwarzają przeciwciała przeciwtarczycowe, głównie skierowane przeciwko receptorom dla TSH (TRAb, thyrotropin receptor antibodies). Połączenie autoprzeciwciał z receptorem TSH (TSH-R) komórek pęcherzykowych tarczycy stymuluje jodowanie tyreoglobuliny i syntezę hormonów tarczycowych [4].

Orbitopatia tarczycowa jest swoistą narządowo chorobą autoimmunologiczną, powstałą w wyniku nietolerancji własnych antygenów. Nagromadzenie autoreaktywnych limfocytów w oczodole może być reakcją na: 1) antygeny ulegające modyfikacji, np. w wyniku mutacji lub infekcji wirusowej, 2) pojawienie się nagle nadmiernej ilości antygenu w krążeniu lub 3) krzyżową reakcję antygenów własnych $\mathrm{z}$ antygenami bakteryjnymi czy wirusowymi. Patogeneza OT nie jest do końca poznana. Badania wskazują, że najbardziej prawdopodobnym autoantygenem, wspólnym dla tarczycy i oczodołu, jest receptor TSH $[5,6]$. Niewykluczona jest także rola innych antygenów tkanki łącznej, w tym receptora IGF1 (IGF1-R, insulin-like growth factor-I receptor) [7].

Według najnowszej hipotezy źródłem toczącego się w oczodole zapalenia jest tkanka łączna, a w niej fibrocyty grupa pochodzących ze szpiku komórek progenitorowych o cechach immunomodulujących, która wykazuje wysoką, porównywalną z komórkami tarczycy, ekspresję TSH-R. Komórki te migrują do oczodołów (tylko u osób z oftalmopatią) i przekształcają się w specyficzne fibroblasty, cechujące się nadmierną ekspresją receptorów powierzchniowych i nadreaktywnością na bodźce prozapalne. Pobudzenie TSH-R na fibrocytach i fibroblastach, przy jednoczesnym pobudzeniu IGF1-R, powoduje uwolnienie cytokin prozapalnych i inicjację zapalenia [7]. W oczodole dochodzi do infiltracji tkanek pozagałkowych komórkami jednojądrzastymi, głównie limfocytami T CD4+ i CD8+, co prowadzi do uwalniania cytokin, które z kolei aktywują albo specyficzne cytotoksyczne limfocyty T (CD8+), albo limfocyty B, wytwarzające autoprzeciwciała. Cytokiny stymulują fibroblasty do syntezy i wydzielania glikozaminoglikanów oraz indukują proliferację fibroblastów oczodołu, co ostatecznie przyczynia się do zwiększenia masy wewnątrzoczodołowej i powstania wytrzeszczu [8]. Ekspresja cytokin jest zmienna w zależności od zaawansowania choroby. We wczesnych stadiach oftalmopatii dominuje aktywność profilu „komórkowego" cytokin Th-1 (interleukina 2, interferon $\gamma$, TNF- $\alpha$ ), natomiast $\mathrm{w}$ stadium zaawansowanym - profilu cytokin Th-2 (interleukiny 4, 5, 10), zwanego "humoralnym”.

Oftalmopatia Gravesa należy do chorób samoograniczających się (self-limited disease) [8]. Wyróżnia się dwie następujące po sobie fazy schorzenia: początkową, aktywną, ze stopniowo narastającymi objawami ocznymi, następnie częściowo cofającymi się, oraz fazę późną, nieaktywną, 
z obecnością resztkowych, utrwalonych zmian ocznych. Nieleczona OT wykazuje tendencję do samoistnego wygaszania aktywności w ciągu 3 do 36 miesięcy; nawroty choroby oczu występują rzadko [4].

\section{OBRAZ KLINICZNY}

Najczęściej występujące objawy podmiotowe OT to: retrakcja powiek, pieczenie oczu, światłowstręt, łzawienie, kłucie, uczucie wypierania gałek ocznych, ból pozagałkowy i ból towarzyszący ruchom oczu. W cięższych przypadkach pojawia się dwojenie, upośledzenie ostrości widzenia i zaburzenia widzenia barwnego, uszkodzenie pola widzenia. W obrazie klinicznym OT występują w różnym nasileniu: 1) objawy oczodołowe (wytrzeszcz), 2) objawy powiekowe (retrakcja powiek, asynergia ruchów gałek i powiek, obrzęk i przekrwienie powiek), 3) objawy ze strony przedniego odcinka gałki ocznej (przekrwienie i obrzęk spojówki gałkowej i mięska łzowego, zastój żylny nad przyczepem mięśnia prostego bocznego, uszkodzenia rogówki), 4) objawy ze strony tylnego odcinka oka (rzadko spotykane: poszerzenie naczyń żylnych, przekrwienie i obrzęk tarczy nerwu wzrokowego, fałdy naczyniówkowe), 5) zaburzenia czynności mięśni gałkoruchowych i 6) podwyższone ciśnienie wewnątrzgałkowe. Zmiany oczne w OT są na ogół obustronne (w 86\%) i w większości przypadków symetryczne [4].

Najcięższymi powikłaniami OT są neuropatia kompresyjna nerwu wzrokowego, owrzodzenia i perforacja rogówki, zwichnięcie gałki ocznej i ślepota. U 25\% nieleczonych chorych z neuropatią wzrokową dochodzi do nieodwracalnej utraty widzenia.

Ciężkość procesu ustala się za pomocą klasyfikacji NOSPECTS oraz określanego na jej podstawie Indeksu Oftalmopatii (IO) według Donaldson (tab. 1) [9]. Oftalmopa- tię definiuje się jako ciężką przy wartościach IO powyżej 6 pkt. Aktywność procesu zapalnego ocenia się za pomocą klasyfikacji CAS (clinical activity score) według Mouritsa [10]. Współczynnik aktywności choroby wyrażony jest jako suma punktów odpowiadających następującym objawom ocznym: samoistny ból pozagałkowy, ból podczas ruchów oczu, przekrwienie powiek, obrzęk powiek, przekrwienie spojówek, obrzęk spojówek, obrzęk mięska łzowego. Współczynnik o wartości równej lub powyżej 3, w 7-stopniowej skali, świadczy o czynnym procesie zapalnym i celowości podjęcia leczenia immunosupresyjnego [10]. Wykazano korelację współczynnika CAS z poziomem przeciwciał anty-TSH-R [11]. Odróżnienie fazy aktywnej od ciężkiej, nieaktywnej, czasami bywa trudne i wymaga przeprowadzenia dodatkowych badań obrazowych oczodołów (NMR, USG, scyntygrafia) w celu prawidłowego kwalifikowania chorych do odpowiedniego leczenia.

\section{LECZENIE NADCZYNNOŚCI TARCZYCY U PACJENTÓW Z OT}

Podstawowymi warunkami uzyskania pozytywnych wyników leczenia zmian ocznych u chorych z nadczynnością tarczycy w przebiegu choroby Gravesa-Basedowa są: przeprowadzenie leczenia w aktywnej fazie oftalmopatii, osiągnięcie trwałej kontroli funkcji tarczycy oraz bezwzględne zaprzestanie palenia przez chorych palących. Wybór optymalnej dla chorego z oftalmopatią metody leczenia nadczynności tarczycy wymaga stworzenia zespołu specjalistów: endokrynologa, okulisty, radioterapeuty i chirurga, oraz uwzględnienia ryzyka nawrotu choroby i możliwych powikłań metody.

Stosowane są trzy metody leczenia hipertyreozy: 1) farmakologiczna, za pomocą doustnych leków przeciwtarczycowych (tyreostatyków), 2) izotopowa, z wykorzystaniem

\section{TABELA 1}

\section{Klasyfikacja ciężkości orbitopatii tarczycowej według Donaldson.}

\begin{tabular}{|c|c|c|c|c|c|}
\hline $\begin{array}{c}\text { Klasa II } \\
\text { Tkanki miękkie oczodołu }\end{array}$ & $\begin{array}{c}\text { Klasa III } \\
\text { Wytrzeszcz }\end{array}$ & $\begin{array}{l}\text { Klasa IV } \\
\text { Mięśnie }\end{array}$ & $\begin{array}{c}\text { Klasa V } \\
\text { Rogówka }\end{array}$ & $\begin{array}{c}\text { Klasa VI } \\
\text { Ostrość wzroku }\end{array}$ & Punkty \\
\hline $\begin{array}{l}\text { Nieznaczne zaczerwienienie } \\
\text { spojówek, } \\
\text { przekrwienie i obrzęk powiek, } \\
\text { minimalne dolegliwości }\end{array}$ & $20-21 \mathrm{~mm}$ & $\begin{array}{l}\text { rzadko dwojenie } \\
\text { (w skrajnych } \\
\text { ustawieniach } \\
\text { oczu) }\end{array}$ & $\begin{array}{l}\text { nieznaczne } \\
\text { podsychanie }\end{array}$ & $0,67-0,33$ & 1 \\
\hline $\begin{array}{l}\text { Umiarkowane zaczerwienienie } \\
\text { spojówek, } \\
\text { obrzęk powiek, } \\
\text { dolegliwości średnio nasilone }\end{array}$ & $21,5-24 \mathrm{~mm}$ & $\begin{array}{l}\text { częste dwojenie, } \\
\text { umiarkowane } \\
\text { ograniczenie } \\
\text { ruchomości gałek } \\
\text { ocznych }\end{array}$ & $\begin{array}{l}\text { wyraźne } \\
\text { podsychanie }\end{array}$ & $0,32-0,1$ & 2 \\
\hline $\begin{array}{l}\text { Duży obrzęk spojówek, } \\
\text { wyraźny obrzęk powiek, } \\
\text { dolegliwości bardzo nasilone }\end{array}$ & powyżej 24 mm & $\begin{array}{l}\text { stałe dwojenie, } \\
\text { ciężka dysfunkcja } \\
\text { mięśni }\end{array}$ & owrzodzenie & poniżej 0,1 & 3 \\
\hline
\end{tabular}

Indeks oftalmopatii = suma punktów nasilenia zmian w 5 klasach NOSPECS (maximum 15 punktów) 
jodu promieniotwórczego ${ }^{131}$ J oraz 3) chirurgiczna, pod postacią subtotalnej lub totalnej tyreoidektomii. W Europie preferowaną metodą leczenia są tyreostatyki, a w USA postępowaniem z wyboru u co drugiego chorego z nadczynnością tarczycy jest leczenie radiojodem.

\section{Tyreostatyki}

Tyreostatyki (karbimazol, propylotiouracyl), wprowadzone do leczenia w połowie lat 40., powodują spadek poziomu hormonów tarczycowych we krwi poprzez hamowanie ich syntezy w gruczole tarczowym. Przypisuje się im także działanie immunomodulujące; na skutek leczenia dochodzi do obniżenia poziomu przeciwciał TRAb. Leki te praktycznie nie wpływają na kliniczny obraz oftalmopatii Gravesa. Są preferowaną metodą leczenia u osób z małym ryzykiem nawrotu nadczynności tarczycy (małe wole, płeć żeńska, niskie miano przeciwciał TRAb). Ujemną stroną terapii tyreostatykami jest długi, wielomiesięczny czas leczenia, działania niepożądane terapii (m.in. gorączka, leukopenia) oraz duży, sięgający nawet $63 \%$, odsetek nawrotów nadczynności tarczycy po ich odstawieniu (z ryzykiem reaktywacji zmian ocznych) [12].

\section{Terapia izotopowa ${ }^{131} \mathrm{~J}$}

Istotą terapii izotopowej za pomocą ${ }^{131} \mathrm{~J}$, wprowadzonej do leczenia w 1946 r., jest uszkodzenie poprzez promieniowanie jonizujące jąder komórek pęcherzykowych tarczycy, z następowym ustaniem ich czynności. Główną zaletą tej metody jest krótki cykl leczenia oraz wysoka skuteczność (odsetek nawrotów wynosi 8\%). Wieloletnie obserwacje wykazały, że przeprowadzenie terapii ${ }^{131} \mathrm{~J}$ nie indukuje wystąpienia zmian ocznych, natomiast u 15-35\% chorych ze współistniejącą oftalmopatią może prowadzić do jej nasilenia. Progresja zmian ocznych może wystąpić w ciągu pierwszych 7 miesięcy po leczeniu radiojodem i ma związek z uwolnieniem antygenów z tarczycy oraz nasileniem reakcji autoimmunologicznej w oczodole na skutek podwyższenia stężenia i aktywności przeciwciał TRAb oraz cytokin zapalnych. Czynnikami ryzyka pogorszenia zmian ocznych po leczeniu ${ }^{131} \mathrm{~J}$ są: palenie tytoniu, wysoki poziom przeciwciał TRAb, obecność zmian ocznych przed leczeniem oraz kolejna terapia radiojodem [13]. W celu profilaktyki progresji oftalmopatii u chorych z czynnikami ryzyka od blisko trzech dekad stosowana jest metoda „osłony steroidowej”, polegająca na trzymiesięcznej terapii prednizonem, począwszy od dnia podania radiojodu. Według zaleceń EUGOGO u pacjentów z wysokim ryzykiem progresji oftalmopatii lub powstania oftalmopatii de novo rekomendowaną dawką jest 0,3-0,5 mg prednizonu/kg mc., natomiast u pacjentów z niskim ryzkiem - 0,2-0,3 mg prednizonu/kg mc. [14, 15]. Przeciwwskazaniami do terapii izotopowej są: ciężka OT, ciąża, karmienie piersią i współistniejący rak tarczycy.

\section{CHIRURGICZNE USUNIĘCIE TARCZYCY}

Chirurgiczne usunięcie tarczycy (tyreoidektomia) jest najrzadziej stosowaną z trzech metod leczenia hipertyreozy. Poprawę stanu okulistycznego obserwowano u 69-81\% chorych leczonych metodą subtotalnej tyreoidektomii. Jednak ograniczona rola tej metody wynika z analizy jej efektywności w stosunku do kosztów oraz ryzyka możliwych powikłań, dlatego stosuje się ją przede wszystkim u pacjentów z bardzo dużym wolem położonym zamostkowo oraz u chorych, którzy nie odpowiedzieli na kilkukrotną terapię jodem promieniotwórczym [16].

\section{Potencjalne metody leczenia nadczynności tarczycy}

W ostatnich latach prowadzono badania nad nowymi, potencjalnymi metodami leczenia nadczynności tarczycy, wykorzystującymi przeciwciała monoklonalne anty-CD20, rytuksymab (wykazano bardzo niską skuteczność) oraz anty-CD40, cząsteczkę CFZ533 (aktualnie prowadzone badanie II fazy). Lekiem przyszłości w terapii choroby Gravesa-Basedowa może się okazać ATX-GD-59, będący kombinacją trzech fragmentów antygenu (epitopów) pochodzących z receptora TSH i wpływający pozytywnie na odpowiedź komórek T i B (obecnie prowadzone są badania przedkliniczne). Innym obiecującym podejściem jest terapia komórkowa, polegająca na pobraniu limfocytów regulatorowych (Treg) od chorych z chorobą Gravesa-Basedowa, aby „wyszkolić” je w rozpoznawaniu swoistego autoantygenu (TSH-R), a następnie ponownie zwrócić do organizmu pacjenta w celu tłumienia reakcji immunologicznej. Obecnie prowadzone jest także badanie I fazy z wykorzystaniem ludzkiego przeciwciała monoklonalnego IgG przeciwko receptorowi TSH (cząsteczka K1-70) [16].

\section{LECZENIE AKTYWNEJ OFTALMOPATII TARCZYCOWEJ}

W przypadku łagodnych, nienaciekowych zmian ocznych pacjenci nie wymagają żadnego leczenia lub wymagają wyłącznie postępowania miejscowego (preparaty nawilżające) czy łagodzącego dolegliwości oczne (uniesienie głowy podczas snu, przyciemniane szkła). W nadciśnieniu ocznym lekami z wyboru są leki zmniejszające produkcję cieczy wodnistej - $\beta$-blokery lub inhibitory anhydrazy węglanowej. W przypadku oftalmopatii naciekowo-obrzękowej stosowane są metody, które mają na celu albo zmniejszenie objętości obrzękłych tkanek wewnątrzoczodołowych, albo zwiększenie wolnej przestrzeni wewnątrz oczodołu. Pierwszy rodzaj postępowania terapeutycznego obejmuje w pierwszej kolejności leczenie immunosupresyjne, które może być wspomagane radioterapią oczodołów; drugi rodzaj postępowania obejmuje chirurgiczną dekompresję oczodołu, która zmniejsza jedynie mechaniczne skutki wytrzeszczu i najczęściej wymaga wcześniejszej albo równoczesnej glikokortykosteroidoterapii. 


\section{Glikokortykosteroidy}

Stanowią leki pierwszego wyboru w leczeniu oftalmopatii naciekowo-obrzękowej i są stosowane od połowy lat 60 . XX w. Mechanizm działania glikokortykosteroidów, wykazujących silne działanie przeciwzapalne i immunosupresyjne, polega na zaburzeniu funkcji limfocytów T i B, zmniejszeniu wychwytu neutrofili, monocytów i makrofagów w strefie objętej procesem zapalnym, hamowaniu funkcji komórek immunokompetentnych oraz hamowaniu uwalniania cytokin. Leki te zmniejszają również syntezę glikozaminoglikanów przez fibroblasty oczodołu. Według wytycznych EUGOGO leczenie OT o średnim lub ciężkim przebiegu należy rozpocząć od podania glikokortykosteroidów dożylnych w postaci cotygodniowych pulsów z metyloprednizolonu: $500 \mathrm{mg}$ przez pierwsze 6 tygodni, następnie 250 mg przez kolejne 6 tygodni (łączna dawka 4,5 g) [14]. Podawanie glikokortykosteroidów za pomocą wlewów dożylnych wiąże się z szybszą poprawą kliniczną i mniejszym nasileniem objawów ubocznych w porównaniu z intensywną i kilkumiesięczną glikokortykosteroidoterapią doustną (średnia dawka 1-2 mg prednizonu/kg mc./24 h w początkowym okresie terapii) [17]. Najczęstszymi działaniami niepożądanymi związanymi z intensywną glikokortykosteroidoterapią są otyłość kuszingoidalna, cukrzyca, choroba wrzodowa, infekcje, nadciśnienie tętnicze, osteoporoza, hirsutyzm, bezsenność i depresja. Ryzyko powikłań śmiertelnych związanych z intensywną glikokortykosteroidoterapią $\mathrm{w}$ tej grupie chorych wynosi $0,57 \%$.

Skuteczność glikokortykosteroidoterapii dożylnej oceniana jest w piśmiennictwie na $80 \%$, a doustnej na 50\%. Wyniki metaanalizy obejmującej 23 badania kliniczne (w tym 9 randomizowanych) wykazały, że zastosowanie większej łącznej dawki metyloprednizolonu (7,5 g) wiązało się z wyższą skutecznością, generowało jednak więcej działań niepożądanych i terapię taką można rozważać tylko w bardzo ciężkich przypadkach oftalmopatii [18]. Pojedyncza dawka metyloprednizolonu nie powinna przekroczyć $1 \mathrm{~g}$, a łączna 8 g [14]. Brak poprawy lub pogorszenie stanu oftalmopatii pomimo 6-tygodniowego leczenia metyloprednizolonem jest negatywnym predyktorem skutecznej immunosupresji. Terapiami drugiego rzutu są dekompresja oczodołów, doustna glikokortykosteroidoterapia w skojarzeniu z radioterapią oczodołów lub cyklosporyną oraz terapie eksperymentalne.

\section{Radioterapia oczodołów}

Przesłanką do stosowania tej metody, obecnej w terapii oftalmopatii Gravesa od ok. 80 lat, jest niespecyficzne działanie przeciwzapalne oraz swoiste działanie immunosupresyjne promieniowania, zarówno na mediatory (limfocyty), jak i efektory (fibroblasty) reakcji immunologicznej w oczodole. Obecnie rekomendowane jest użycie skolimowanej wiązki promieniowania, generowanej przez akcelerator li- niowy oraz 10 dawek frakcjonowanych po 2 Gy każda, podawanych w ciągu 2 tygodni. Efekty radioterapii ujawniają się po kilku miesiącach od naświetlań. Radioterapia jako metoda izolowana nie jest skuteczna [16]. Opisana przez Bartalenę i wsp. [19] w 1983 r. metoda skojarzonego podawania wysokich dawek glikokortykosteroidów i telekobaltoterapii oczodołów pozwoliła uzyskać 75-procentowy odsetek korzystnych wyników, przy istotnym skróceniu czasu leczenia (średnio o 30\%), i tym samym zmniejszeniu działań ubocznych glikokortykosteroidoterapii.

\section{Dekompresja oczodołów}

Głównym wskazaniem do leczenia chirurgicznego jest kompresyjna neuropatia wzrokowa oraz ciężki wytrzeszcz z keratopatią. Wybór techniki chirurgicznej, poza preferencjami zespołu chirurgicznego, powinien mieć związek z indywidualnym obrazem klinicznym choroby [16]. W przypadku kompresyjnej neuropatii wzrokowej zalecaną przez wielu autorów metodą jest usunięcie dolnej i przyśrodkowej ściany oczodołu z wejścia przezprzedsionkowego. $\mathrm{U}$ chorych bez przedoperacyjnego dwojenia preferowaną metodą w niektórych ośrodkach jest technika usunięcia trzech ścian oczodołu z dojścia przezpowiekowego, gdyż charakteryzuje się najmniejszym (19-procentowym) ryzykiem pooperacyjnej diplopii. Inną metodą chirurgicznej dekompresji jest usunięcie samego tłuszczu oczodołowego drogą górno-przyśrodkowej lub dolno-bocznej orbitotomii przedniej. Z każdą techniką wiąże się ryzyko działań niepożądanych, takich jak jatrogenne dwojenie, zaburzenia ustawienia powiek, znieczulica czoła, trudności w żuciu, obrzęk i drętwienie policzka [12].

W ciągu ostatnich kilku dekad prowadzono badania nad innymi propozycjami terapii, m.in. wykorzystującymi analogi somatostatyny [20] czy immunoglobuliny [21].

\section{Analogi somatostatyny}

W terapii tej wykorzystano fakt obecności na powierzchni uczynnionych limfocytów oczodołu receptorów dla somatostatyny oraz zwiększonego oczodołowego wychwytu syntetycznego analogu somatostatyny. Dotychczasowe badania nie potwierdziły wyższej skuteczności oktreotydu i lanreotydu względem glikokortykosteroidoterapii lub placebo, przy jednoczesnych bardzo wysokich kosztach leczenia. Leki te można rozważać u pacjentów z krótkim czasem trwania aktywnej fazy oftalmopatii [20].

\section{Immunoglobuliny}

Ich skuteczność w leczeniu oftalmopatii Gravesa jest prawdopodobnie spowodowana hamowaniem syntezy przeciwciał przez blokowanie receptorów na powierzchni limfocytów B oraz zmniejszaniem uwalniania cytokin. Głównym czynnikiem ograniczającym stosowanie tej metody jest jej bardzo wysoki koszt. Metoda ta może znaleźć 
zastosowanie w leczeniu ciężkiej oftalmopatii, opornej na glikokortykosteroidoterapię dożylną i radioterapię oczodołów. Polscy badacze opisali skuteczną terapię eksperymentalną za pomocą globuliny antytymocytowej w leczeniu ciężkiej i opornej na leczenie oftalmopatii u 47-letniej chorej [21].

W ostatnich latach uzyskano obiecujacce wyniki leczenia OT z zastosowaniem przeciwciał monoklonalnych, inhibitorów cytokin czy selektywnych związków immunosupresyjnych.

\section{Rytuksymab}

Rytuksymab jest humanizowanym chimerycznym przeciwciałem monoklonalnym przeciwko kompleksowi CD20 obecnemu na powierzchni komórek B. Skuteczność tego leku oceniono w dwóch randomizowanych badaniach klinicznych (RCT). W pierwszym, z pojedynczą ślepą próbą, porównywano rytuksymab (stosowany dożylnie $\mathrm{w}$ dawce $2000 \mathrm{mg}$ ) z dożylnie podawanym metyloprednizolonem (łączna dawka 7,5 g); po 24 tygodniach leczenia nastąpiło zmniejszenie wskaźnika CAS z 4,4 do 1,6 w grupie leczonej rytuksymabem i z 4,7 do 2,3 w grupie leczonej metyloprednizolonem [22]. W drugim badaniu, z podwójnie ślepą próbą, w którym rytuksymab porównywano z placebo $(0,9 \% \mathrm{NaCl})$, nie wykazano istotnej różnicy między lekiem badanym a lekiem porównawczym. U dwóch pacjentów zaobserwowano nawet pogorszenie stanu oczu i rozwój neuropatii wzrokowej w trakcie terapii rytuksymabem [23]; przypuszcza się, że do jej powstania doszło w mechanizmie jatrogennego, gwałtownie narastającego obrzęku w oczodole powstałego na skutek masywnego rozpadu limfocytów B.

\section{Tocilizumab}

Jest to humanizowane przeciwciało monoklonalne $\operatorname{IgG}_{1}$, które wiąże się z receptorami interleukiny 6. W badaniu Perez-Moreiras i wsp. [24] leczono 18 chorych z aktywną oftalmopatią tarczycową, którzy nie odpowiedzieli pozytywnie na wcześniejszą terapię metyloprednizolonem. U 13 chorych uzyskano średnie obniżenie CAS o 5,9 pkt i zmniejszenie wytrzeszczu o $3,9 \mathrm{~mm}$; poprawę ruchomości gałek ocznych zanotowano u 15 leczonych. Wykazano skuteczność tocilizumabu (łącznie 4 dawki leku $8 \mathrm{mg} / \mathrm{kg}$ mc. podawane co 4 tygodnie) jako leku pierwszego wyboru w leczeniu neuropatii wzrokowej w przebiegu OT [25]. Dotychczas nie opublikowano wyników żadnego badania randomizowanego z zastosowaniem tego leku.

\section{Teprotomumab}

Jest to przeciwciało blokujące IGF1-R w fibrocytach oczodołu. W badaniach fazy II i fazy III, w których uczestniczyło 170 pacjentów, lek podawano w postaci wlewów co 3 tygodnie (łącznie 8 wlewów) i porównywano z placebo.
Po 24 tygodniach stwierdzono, że u 83\% pacjentów leczonych teprotomumabem nastąpiła redukcja wytrzeszczu o ponad $2 \mathrm{~mm}$ (w porównaniu do $10 \%$ chorych leczonych placebo), a u $53 \%$ chorych nastąpiło całkowite ustąpienie dwojenia (w porównaniu do $25 \%$ chorych z grupy placebo). Poprawę stanu klinicznego notowano między 6. a 12. tygodniem terapii. Stwierdzono wówczas średnią redukcję CAS o 3,4 pkt oraz zmniejszenie wytrzeszczu o średnio 2,5 mm. Większość działań niepożądanych podczas badań była łagodna do umiarkowanych. Najczęstsze reakcje obejmowały nudności, biegunkę, wypadanie włosów, zmęczenie, hiperglikemię, zaburzenia smaku i bóle głowy [26, 27]. Lek został zarejestrowany przez FDA w styczniu 2020 r. do leczenia chorych z aktywną oftalmopatią tarczycową.

\section{Inhibitory TNF-a}

Duże oczekiwania wiązano z terapiami, w których zastosowano blokery TNF- $\alpha$ : etanercept i adalimumab. Zakładano, że zahamowanie aktywności jednej z głównych cząsteczek profilu „komórkowego” cytokin Th-1, dominującego we wczesnych stadiach oftalmopatii, może mieć korzystny wpływ na jej dalszy przebieg. Po 12 tygodniach terapii u 6 z 10 chorych leczonych etanerceptem $(25 \mathrm{mg}$ podskórnie 2 razy w tygodniu) i u 5 z 10 leczonych adalimumabem stwierdzono zmniejszenie objawów zapalnych, leczenie jednak nie wpłynęło istotnie na redukcję ciężkości oftalmopatii. U 3 z 10 chorych leczonych etanerceptem nastąpił nawrót oftalmopatii po zakończeniu leczenia [28]. U 3 z 10 chorych leczonych adalimumabem nastąpiło pogorszenie stanu oczu pomimo leczenia, dodatkowo u jednego pacjenta rozwinęła się sepsa. W literaturze opisano korzystny wpływ innego blokera TNF- $\alpha$, infliksimabu, w leczeniu neuropatii wzrokowej w przebiegu OT [16]. Dotychczas nie opublikowano wyników żadnego badania randomizowanego z zastosowaniem inhibitorów TNF- $\alpha$.

\section{Selektywne immunosupresanty - mykofenolat mofetylu}

Jest to selektywny środek immunosupresyjny, działający na limfocyty B i T. W postaci przekształconej do aktywnego metabolitu, kwasu mykofenolowego, hamuje dehydrogenazę monofosforanu inozyny, która jest głównym enzymem syntezy puryn. Mykofenolat mofetylu zmniejsza także wytwarzanie przeciwciał oraz napływ leukocytów i monocytów do miejsc zapalnych. Lek ten wykazuje wysoki profil bezpieczeństwa i jest dobrze tolerowany. Jego skuteczność oceniono w dwóch badaniach klinicznych. W pierwszym, z pojedynczą ślepą próbą, porównywano mykofenolat mofetylu (stosowany w dawce $2000 \mathrm{mg}$ ) z dożylnie podawanym metyloprednizolonem (łączna dawka 7,5 g). Po 24 tygodniach leczenia poprawę kliniczną zaobserwowano u 93\% chorych leczonych mykofenolatem mofetylu w porównaniu z 71\% chorych w grupie leczonej glikokortykosteroidami, co więcej - tempo poprawy stanu oczu było 
szybsze w grupie leczonej mykofenolatem mofetylu. Także zmniejszenie wytrzeszczu notowano w większej grupie osób przyjmujących ten lek w porównaniu z osobami leczonymi metyloprednizolonem ( $90,4 \%$ vs $68,8 \%$ ), co sugeruje, że mykofenolat mofetylu może być bardziej skuteczny i bezpieczny dla chorych z aktywną umiarkowaną do ciężkiej oftalmopatią tarczycową niż glikokortykosteroidy [29]. W drugim badaniu analizowano potencjalny efekt addytywny mykofenolatu mofetylu w skojarzeniu z metyloprednizolonem i porównywano skuteczność terapii skojarzonej z samym metyloprednizolonem. Po 12 tygodniach leczenia obie interwencje nie różniły się pod względem skuteczności, także po 24 i 36 tygodniach nie wykazano różnic w odsetku nawrotów [30]. Do określenia pełnego potencjału mykofenolatu mofetylu w leczeniu OT konieczne jest przeprowadzenie randomizowanego, wieloośrodkowego badania klinicznego.

\section{PODSUMOWANIE}

Złotym standardem w leczeniu orbitopatii tarczycowej jest leczenie immunosupresyjne za pomocą dożylnych glikokortykosteroidów, w ciężkich przypadkach skojarzone z teleradioterapią oczodołów. Poznanie mechanizmów molekularnych determinujących pobudzenie fibrocytów i fibroblastów w oczodole zapoczątkowało rozwój nowej strategii leczenia oftalmopatii Gravesa, immunoterapii, wykazującej większą specyficzność działania przy jednoczesnym akceptowalnym profilu bezpieczeństwa terapii. Ta celowana strategia jest oparta na lekach ukierunkowanych na zablokowanie kluczowych szlaków patogenezy OT i po raz pierwszy otwiera możliwość leczenia spersonalizowanego u chorych z OT.

\section{ADRES DO KORESPONDENCJI}

dr hab. n. med. Joanna Wierzbowska, prof. WIM

Klinika Okulistyki, Centralny Szpital Kliniczny Ministerstwa

Obrony Narodowej, Wojskowy Instytut Medyczny

04-141 Warszawa, ul. Szaserów 128

ORCID

e-mail: jwierzbowska@wim.mil.pl

Joanna Wierzbowska - ID - https://orcid.org/0000-0002-6993-7518

\section{Piśmiennictwo}

1. Tanda ML, Piantanida E, Liparulo L et al. Prevalence and natural history of Graves' orbitopathy in a large series of patients with newly diagnosed graves' hyperthyroidism seen at a single center. Clin Endocrinol Metab. 2013; 98: 1443-9. https://doi.org/10.1210/jc.20123873.

2. Hiromatsu Y, Eguchi H, Tani J et al. Graves' ophthalmopathy: epidemiology and natural history. Intern Med. 2014; 53: 353-60.

3. Sawicka-Gutaj N, Gutaj P, Sowiński J et al. Influence of cigarette smoking on thyroid gland-an update. Endokrynol Pol. 2014; 65: 54-62. https://doi.org/10.5603/EP.2014.0008.

4. Wiersinga WM. Graves' ophthalmopathy. Thyroid International 1997; 3: 1-15.

5. Blandford AD, Zhang D, Chundury RV et al. Dysthyroid optic neuropathy: update on pathogenesis, diagnosis, and management. Expert Rev Ophthalmol. 2017; 12: 111-21. https://doi.org/10.1080/17469899.2017.1276444.

6. Heufelder AE, Dutton CM, Sarkar G et al. Detection of TSH receptor mRNA in cultured fibroblasts from patients with Graves' ophthalmopathy and pretibial dermopathy. Thyroid 1993; 3: 297-300.

7. Wang Y, Smith TJ. Current concepts in the molecular pathogenesis of thyroid-associated ophthalmopathy. Invest Ophthalmol Vis Sci. 2014; 55: 1735-48.

8. Yeatts RP. Graves' ophthalmopathy. Med Clin North Am. 1995; 79: 195-209.

9. Donaldson SS, Bagshaw MA, Kriss P. Supervoltage orbital radiotherapy for Graves' ophthalmopathy. J Clin Endocrinol Metab. 1973; 37: 276-85.

10. Mourits MP, Koorneef L, Wiersinga WM et al. Clinical criteria for the assessment of disease activity in Graves' ophthalmopathy: a novel approach. Br J Ophthalmol. 1989; 73: 639-44.

11. Gerding MN, van der Meer JWC, Broenink M et al. Association of thyrotropin receptor antibodies with the clinical features of Graves' ophthalmopathy. Clin Endocrinol. 2000; 52: 267-71.

12. Drui D, Du Pasquier Fediaevski L, Vignal Clermont C et al. Graves' orbitopathy: Diagnosis and treatment. Ann Endocrinol (Paris). 2018; 79: 656-64. https://doi.org/10.1016/j.ando.2018.08.005.

13. Ruchała M, Sawicka-Gutaj N. Advances in the pharmacological treatment of Graves' orbitopathy. Expert Rev Clin Pharmacol. 2016; 9: 981-9. https://doi.org/:10.1586/17512433.2016.1165606.

14. Bartalena L, Baldeschi L, Dickinson A et al. European Group on Graves' Orbitopathy (EUGOGO) Consensus statement of the European Group on Graves' orbitopathy (EUGOGO) on management of GO, Eur J Endocrinol. 2008; 158(3): 273-85. 
15. Shiber S, Stiebel-Kalish H, Shimon I et al. Glucocorticoid regimens for prevention of Graves' ophthalmopathy progression following radioiodine treatment: systematic review and meta-analysis. Thyroid. 2014; 24: 1515-23. https://doi.org/10.1089/thy.2014.0218.

16. Kotwal A, Stan M. Current and Future Treatments for Graves' Disease and Graves' Ophthalmopathy. Horm Metab Res. 2018; 50: 871-86. https://doi.org/10.1055/a-0739-8134.

17. Miśkiewicz P, Kryczka A, Ambroziak U et al. Is high dose intravenous methylprednisolone pulse therapy in patients with Graves' orbitopathy safe? Endokrynol Pol. 2014; 65(5): 402-13. https://doi.org/10.5603/EP.2014.0056.

18. Zang S, Ponto KA, Kahaly GJ. Clinical review: Intravenous glucocorticoids for Graves' orbitopathy: efficacy and morbidity. J Clin Endocrinol Metab. 2011; 96: 320-32. https://doi.org/10.1210/jc.2010-1962.

19. Bartalena L, Marcocci C, Chiovato L et al. Orbital cobalt irradiation combined with systemic corticosteroids for Graves' ophthalmopathy: comparision with systemic corticosteroids alone. J Clin Endocrinol Metab. 1983; 56(6): 1139-44.

20. Stan MN, Garrity JA, Bradley EA et al. Randomized, double-blind, placebo-controlled trial of long-acting release octreotide for treatment of Graves' ophthalmopathy. J Clin Endocrinol Metab. 2006; 91: 4817-24.

21. Świerkot M, Kulawik G, Sarnat-Kucharczyk M et al. Long-term remission of steroid-resistant Graves' orbitopathy after administration of anti-thymocyte globulin. Endokrynol Pol. 2020; 71(2): 198-9. https://doi.org/10.5603/EP.a2019.0067.

22. Stan MN, Garrity JA, Carranza Leon BG et al. Randomized controlled trial of rituximab in patients with Graves' orbitopathy. J Clin Endocrinol Metab. 2015; 100(2): 432-41. https://doi.org/10.1210/jc.2014-2572.

23. Salvi M, Vannucchi G, Currò N et al. Efficacy of B-cell targeted therapy with rituximab in patients with active moderate to severe Graves' orbitopathy: a randomized controlled study. J Clin Endocrinol Metab. 2015; 100: 422-31. doi: 10.1210/jc.2014-3014.

24. Pérez-Moreiras JV, Alvarez-López A, Gómez EC. Treatment of active corticosteroid-resistant graves' orbitopathy. Ophthalmic Plast Reconstr Surg. 2014; 30: 162-7. https://doi.org/10.1097/IOP.0000000000000037.

25. Pascual-Camps I, Molina-Pallete R, Bort-Martí MA et al. Tocilizumab as first treatment option in optic neuropathy secondary to Graves' orbitopathy. Orbit. 2018; 37: 450-3. https://doi.org/10.1080/01676830.2018.1435694.

26. Smith TJ, Kahaly GJ, Ezra DG et al. Teprotumumab for Thyroid-Associated Ophthalmopathy. N Engl J Med. 2017; 376: 1748-61. https:// doi.org/10.1056/NEJMoa1614949.

27. Krieger CC, Place RF, Bevilacqua C et al. TSH/IGF-1 Receptor Cross Talk in Graves' Ophthalmopathy Pathogenesis. J Clin Endocrinol Metab. 2016; 101: 2340-7. https://doi.org/10.1210/jc.2016-1315.

28. Paridaens D, van den Bosch WA, van der Loos TL et al. The effect of etanercept on Graves' ophthalmopathy: a pilot study. Eye (Lond). 2005; 19: $1286-9$.

29. Ye X, Bo X, Hu X et al. Efficacy and safety of mycophenolate mofetil in patients with active moderate-to-severe Graves' orbitopathy. Clin Endocrinol (Oxf). 2017; 86: 247-55. https://doi.org/10.1111/cen.13170.

30. Kahaly GJ, Riedl M, König J et al. Mycophenolate plus methylprednisolone versus methylprednisolone alone in active, moderate-to-severe Graves' orbitopathy (MINGO): a randomised, observer-masked, multicentre trial. Lancet Diabetes Endocrinol. 2018; 6: 287-98. https://doi.org/10.1016/S2213-8587(18)30020-2.

Konflikt interesów:

Nie wystęuje.

Finansowanie:

Nie występuje.

Etyka:

Treści przedstawione w artykule są zgodne z zasadami Deklaracji Helsińskiej,

dyrektywami EU oraz ujednoliconymi wymaganiami dla czasopism biomedycznych.
Conflict of interest:

None.

Financial support:

None.

Ethics:

The content presented in the article complies with the principles of the Helsinki Declaration, EU directives and harmonized requirements for biomedical journals. 